\title{
37. FISSION TRACK AGE OF MAGNETIC ANOMALY M-ZERO AND SOME ASPECTS OF SEA-WATER WEATHERING
}

\author{
Dieter Storzer, Muséum National d'Histoire Naturelle, Laboratoire de Minéralogie, Paris, France \\ and \\ Madeleine Selo, Laboratoire de Géologie Dynamique, Université Paris VI, France
}

\begin{abstract}
The samples analyzed were recovered from Holes 417A, 417D, and 418 A during DSDP Legs 51 and 52. The uranium contents of the fresh remnants of unweathered glasses range between 18 and $50 \mathrm{ppb}$, very low values when compared to modern mid-ocean ridge (MOR) basalts from the Atlantic. The basalts from all three holes are highly altered to various extents. The general tendency is that the degree of alteration decreases with depth.

The measured fission track ages decrease with depth from 76 to 46 m.y. These ages are all thermally lowered and require correction. The ages corrected for the thermal, partial track loss converge to a mean of $108.3 \pm 1.3 \mathrm{~m} . \mathrm{y}$., which is interpreted as the age of magnetic anomaly M0.
\end{abstract}

\section{INTRODUCTION}

Among basalts altered to various extents, glasses suitable for fission track dating were recovered during DSDP Legs 51 and 52 from the southern extremity of the Bermuda Rise. All holes (417A, 417D, and 418A) lie on oceanic crust defined by magnetic anomaly $M 0$. These Cretaceous basalts provide an excellent opportunity for studying alteration processes because uranium is a sensitive tracer for sea-water weathering, becoming gradually enriched with the degree of basalt alteration, i.e., the sample exposure age on the ocean floor (Storzer and Selo, 1976). In addition, this report presents the fission track age of magnetic anomaly $M 0$.

\section{EXPERIMENTAL PROCEDURE}

To separate suitable glasses for fission track dating, the glass-rich parts within the basalts were disintegrated and etched in $4 \%$-ic $\mathrm{HF}$ for 10 minutes following a procedure described previously (Storzer, 1970). Aliquots of each separate were annealed at $350^{\circ} \mathrm{C}$ for several hours to erase the fossil fission tracks, and then irradiated with thermal neutrons to induce a sufficiently high number of fissions for convenient counting. All unirradiated and irradiated glasses were embedded in epoxy, polished, and the latent fission tracks etched under precisely controlled conditions for 35 seconds at $19^{\circ} \mathrm{C}$ in the following mixture: 2 volumes 48 per cent $\mathrm{HF}+1$ volume 96 per cent $\mathrm{H}_{2} \mathrm{SO}_{4}+1$ volume 65 per cent $\mathrm{HNO}_{3}+6$ volumes $\mathrm{H}_{2} \mathrm{O}$. The special dating procedure is described elsewhere (Storzer, 1970; Storzer and Wagner, 1969). Due to the extremely low uranium content in the glasses and its heterogeneous distribution, areas up to 500 $\mathrm{mm}^{2}$ had to be scanned for fossil as well as induced tracks to arrive at plausible ages. This was done by successively polishing down $(\geqslant 20 \mu \mathrm{m})$ and re-etching the available surfaces. For the age calculation, the decay constant $\lambda_{f}=8.46$ $\times 10^{-17} \mathrm{a}^{-1}$ (Galliker et al., 1970) was used.
The uranium contents of the pure glass phases were determined by converting the density of internally induced fission tracks to the corresponding uranium concentration (internal track detector method, Selo and Storzer, 1974). For comparison, the external track detector method (Kleeman and Lovering, 1967) was applied to the glasses and the basalts to measure uranium and its distribution in the bulk and in the main constituent mineral phases. Sandwiches of thin sections, together with NBS standards SRM-615, covered with Kapton as external track detectors (Storzer and Selo, 1974) were irradiated with an integrated thermal neutron flux of $8.6 \times 10^{16} \mathrm{n} / \mathrm{cm}^{2}$. Two or three sections $(1.2 \times$ $2.0 \mathrm{~cm}$ in size) from each sample were analyzed. The latent induced fission tracks recorded in the Kapton foils were developed by etching all the foils together for 8 minutes in a boiling solution of 14 per cent $\mathrm{NaClO} \times 12$ per cent $\mathrm{NaCl}$. The accuracy of the uranium analyses is about 2 to 3 per cent for the bulk values, and between 10 and 30 per cent for the individual mineral phases.

\section{RESULTS AND DISCUSSION}

\section{Uranium Contents and Distribution}

The uranium contents of the fresh, unweathered glasses, which very probably represent the pristine U-concentrations of the extruding magmas, range between 18 and $50 \mathrm{ppb}$ (Table 1). Furthermore, the uranium is extremely inhomogeneously distributed. Concentrated in schlieren and patches, it may vary within one millimeter by factors up to 20 to 30 . The above concentrations are very low compared to modern Mid-Atlantic Ridge basalts, e.g., from the FAMOUS area which have U-contents ranging between 75 and $450 \mathrm{ppb}$ (Storzer and Selo, 1974, 1976). However, the samples under study are comparable to U-contents of basalts from the fast-spreading East Pacific Rise (unpublished results). As a general rule, it could be speculated that low 
TABLE 1

Location of Samples Within the Drill Cores and Their Uranium Contents

\begin{tabular}{|c|c|c|c|c|c|c|}
\hline Lab. No. & Leg & Hole & $\begin{array}{c}\text { Sample } \\
\text { (Interval in cm) }\end{array}$ & $\begin{array}{l}\text { Sub-Bottom } \\
\text { Depth (m) }\end{array}$ & $\begin{array}{c}\text { Uranium Content } \\
\text { Glass }^{\mathrm{a}}\end{array}$ & $\begin{array}{l}\text { Basalt }^{\mathrm{b}} \\
(\mathrm{ppb})\end{array}$ \\
\hline A1 & 51 & $417 \mathrm{~A}$ & $24-3,90-94$ (\#6) & $\sim 220$ & & 253,274 \\
\hline A2 & & & $28-5,88-92(\# 5)$ & $\sim 260$ & & 117,151 \\
\hline A3 & & & $30-2,93-97(\# 6)$ & $\sim 280$ & & 271 \\
\hline A4 & & & $40-3,91-95(\# 2 b)$ & $\sim 365$ & & $86.5,149,349$ \\
\hline A5 & & & $43-2,56-60(\# 1 b)$ & $\sim 393$ & & 77.8 \\
\hline A6 & & & $44-4,27-31(\# 1 B)$ & $\sim 397$ & & 57.1 \\
\hline A7 & & & $46-2,12-16(\# 2)$ & $\sim 415$ & & $59.9,168$ \\
\hline A8 & 51 & 417D & 22 , top of basalt core & $\sim 344$ & 40.0 & \\
\hline A9 & & & $22-4,124-127 \# 8$ & $\sim 350$ & 24.3 & $285-450,298,408$ \\
\hline A 10 & & & $27-7,2-6 \# 1$ & $\sim 367$ & 39.0 & 363 \\
\hline A11 & & & $28-5,137-141 \# 5$ & $\sim 380$ & $34.0(37.4)$ & 120 \\
\hline A12 & & & $28-6,2-6 \# 1$ & $\sim 383$ & 26.4 & 2400 \\
\hline A13 & & & $30-5,73-77 \# 2 c$ & $\sim 400$ & $31.8(37.9)$ & $417-441,197-680$ \\
\hline A14 & & & $30-5,95-101 \# 5 B$ & $\sim 400$ & 36.3 & 1430 \\
\hline A 15 & & & $30-6,21-25 \# 3$ & $\sim 402$ & $26.7(43.2)$ & 63.3 \\
\hline A16 & & & $31-3,136-139 \# 3$ & $\sim 408$ & 31.8 & \\
\hline A 17 & & & $31-4,5-8 \# 1$ & $\sim 409$ & $23.1(37.6)$ & 186,332 \\
\hline A18 & & & $32-1,75-76$ \#6 & $\sim 413$ & (47.9) & 800 \\
\hline A19 & & & $43-1,122-125 \# 5$ & $\sim 495$ & $40.1(49.1)$ & $284-3660,124$ \\
\hline A20 & & & $43-7,45-52 \# 4 B$ & $\sim 500$ & $41.6(40.7)$ & $72-157,661$ \\
\hline A21 & 52 & 417D & $53-1,5-6$ & $\sim 567$ & 38.7 & 116 \\
\hline A22 & & & $55-3,5-6$ & $\sim 590$ & $(38.7)$ & 67 \\
\hline A23 & & & $62-6, \# 2 a$ & $\sim 650$ & 49.5 & 95.4 \\
\hline A 24 & & & $66-6,38-41(\# 3 b)$ & $\sim 686$ & 42.4 & \\
\hline A 25 & 52 & $418 \mathrm{~A}$ & $30-2,71-72$ & $\sim 418$ & $21.4(37.0)$ & 44.5 \\
\hline A 26 & & & $45-2,34-37(\# 1)$ & $\sim 540$ & $18.4(19.7)$ & \\
\hline
\end{tabular}

${ }_{b}^{\mathrm{a}}$ Determined by means of the internal detector method.

blass values in parentheses and under "Basalt" - external detector method.

U-contents occur at fast-spreading ridges and higher concentrations occur at slowly spreading ones.

Compared to the fresh glass remnants, the bulk Ucontents of the altered glasses and basalts are generally enriched from 2 to 100 times that of the unweathered reference sample (Table 1, Figures 1 through 3), indicative of the high and variable degree of alteration. The Uenrichment is due to the presence of secondary minerals as smectite with U-contents as high as $3 \mathrm{ppm}$ (Figures 2 and $3)$. There is a general tendency for the U-enrichment (hence, the degree of alteration) to decrease with depth. The severely altered basalts from Hole $417 \mathrm{~A}$ are noteworthy in that they contain high amounts of potassium. Concerning the uranium, no drastic differences in the bulk contents are visible between basalts from Hole $417 \mathrm{~A}$ and the glassbearing basalts from Holes 417D and 418A. During seawater weathering of basaltic material, the saturation level for uranium is probably reached prior to that of potassium.

The U-contents obtained for the glasses within the thin sections by means of the external detector method are mostly higher (up to $4 \mathrm{ppm}$ for totally palagonitized glasses) than the values measured with the internal method (Figure 3 ). Only the latter method allows localization and elimination of slightly altered zones within the glasses, like the beginning of palagonitization. On external detectors, only strongly altered zones like altered minerals or the fillings of fissures are detectable. These fissures within fresh glasses contain up to $1.6 \mathrm{ppm}$ uranium. Light-colored transparent narrow veins (probably calcite), preferentially in samples from Hole 417A, have U-contents between 20 and 39 ppb.

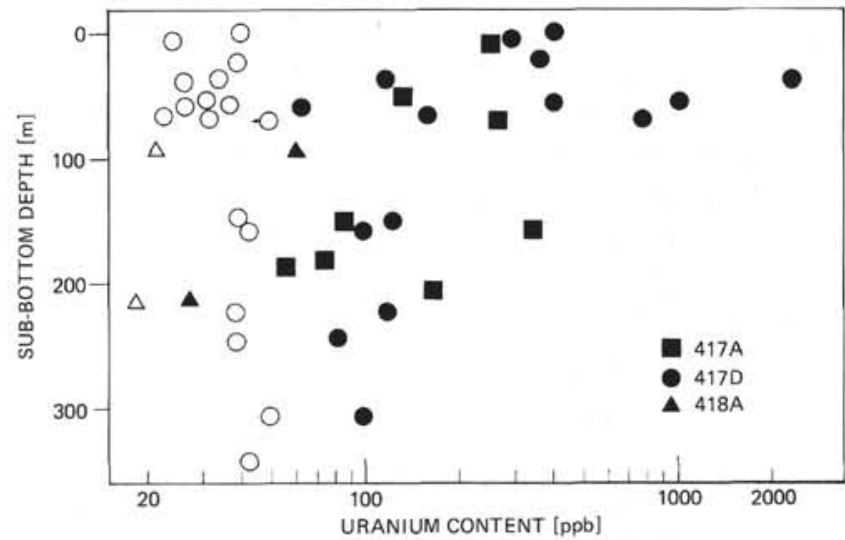

Figure 1. Uranium contents of glasses (open symbols) and basalts (closed symbols) versus sample depth.

On the other hand, the massive calcite veins (up to $5 \mathrm{~mm}$ thick) in samples from 417D show virtually homogeneously distributed uranium with various concentrations ranging between $440 \mathrm{ppb}$ and $3.9 \mathrm{ppm}$. Olivines are always altered and have U-contents between 3 and $440 \mathrm{ppb}$. These values have to be compared with 0.2 to $0.9 \mathrm{ppb}$ of fresh olivines (Storzer and Selo, 1976). Remnants of unaltered feldspars with 2 to $10 \mathrm{ppb} \mathrm{U}$ are rare in Hole 417A and occur there only in the deeper levels. They are more frequent in Holes 417D and $418 \mathrm{~A}$, even in the upper levels. However, these apparently unaltered feldspars are rather frequently surrounded by 50 to $110-\mu \mathrm{m}$-thick alteration rims with $\mathrm{U}$-contents up to 4 


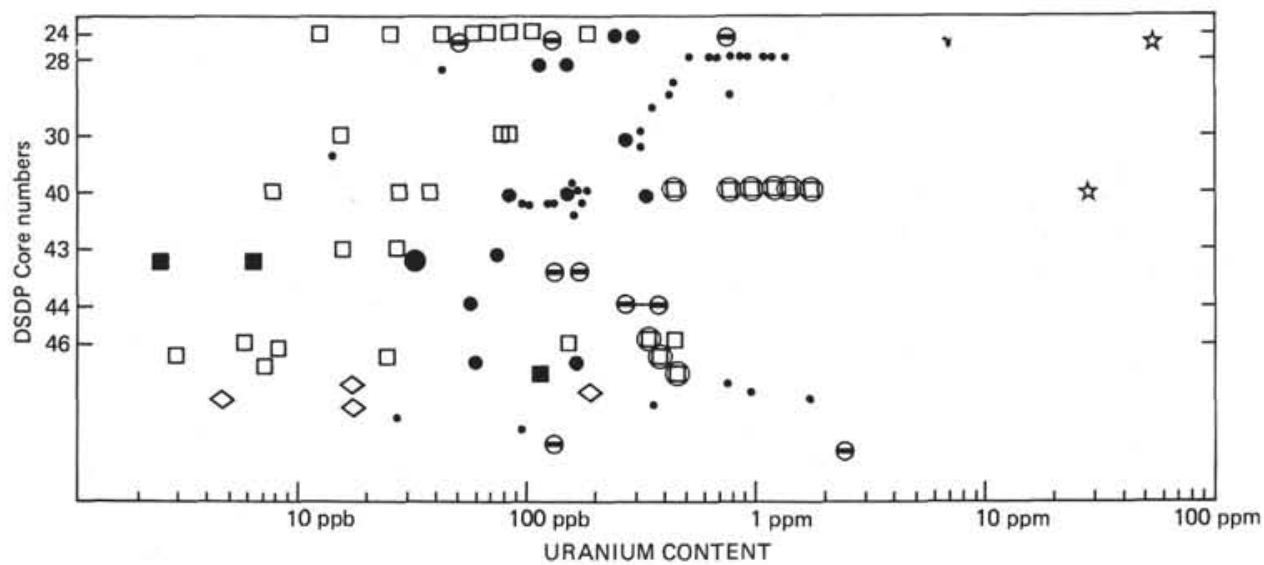

Figure 2. Uranium contents of basalts (•) from Hole $417 \mathrm{~A}$ and their main constituent mineral phases: $\square=$ feldspar; $\mathbf{\|}=$ olivine $; \boldsymbol{\theta}=$ alteration rims around crystals; $\boldsymbol{\theta}=$ white inclusions, probably totally altered feldspars; $\bullet=$ smectite; $;=$ small, $(5$ to 20 $\mu \mathrm{m})$ unidentified inclusions; $\diamond=$ unidentified white inclusions.

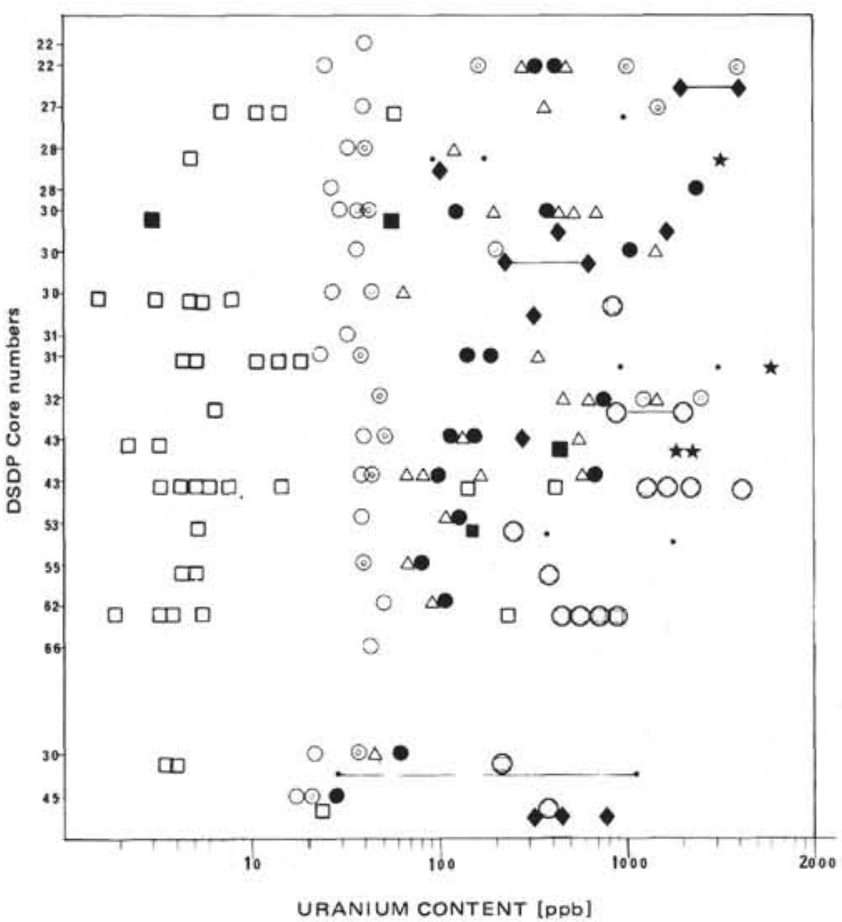

Figure 3. Uranium contents of different phases in basalts from Hole $417 D$ (Cores 22 to 66) and $418 \mathrm{~A}$ (Cores 30 and 45$) . \mathrm{O}=$ glass, internal detector; $\odot=$ glass, external detector; $\Delta=$ basalt $; \bullet=$ bulk values of the whole thin section; = fissure filling or vein; the other symbols are the same as in Figure 2.

ppm (Figure 4). Similar concentrations are found for alteration zones along the crystal cleavages or for totally altered feldspars.

Concerning basalt alteration in the submarine environment, it is currently observed that the enrichment of the bulk $\mathrm{U}$-content is accompanied by an even more intense increase of the bulk potassium content. This is indicative that the local enrichments around the feldspars are not only restricted to uranium, but also hold for potassium (among other ele-

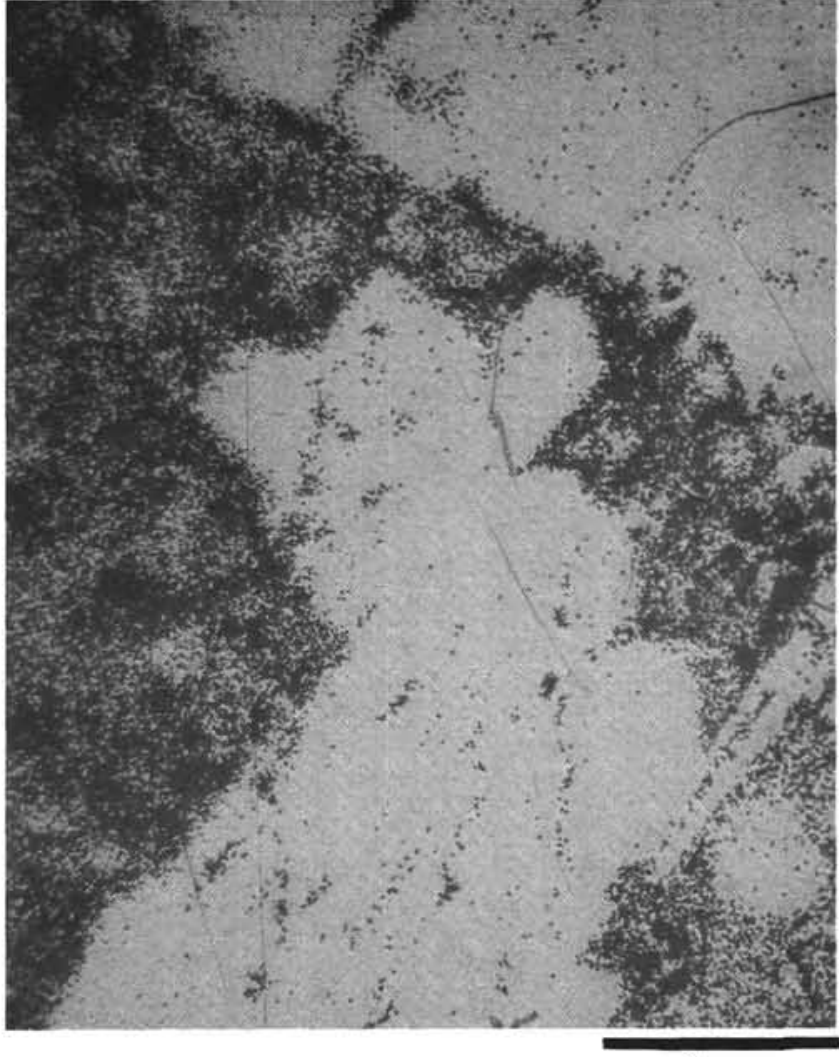

$1 \mathrm{~mm}$

Figure 4. Fission track map showing the U-distribution around and within a feldspar. (Sample from Section 417D-32-1).

ments). However, a local increase of potassium around the feldspars and along their cleavages, if a general rule, would make questionable the K-Ar ages of oceanic basalts. In this case, only the fission track method would give reliable ages.

Finally, isotopic and mineralogical studies at Holes 417A and 417D seem to indicate that the ambient temperatures 
prevailing during the alteration process were rather low at $20^{\circ}$ to $30^{\circ} \mathrm{C}$ (Fouillac and Javoy, 1978). However, from the fission track retention properties of the glasses investigated, it easily can be shown that even millions of years after their formation, the glasses were exposed to relatively high temperatures due to a steep thermal gradient of about $75^{\circ} \mathrm{C} / 100$ $\mathrm{m}$ (the results of the fission track thermometry will be described in detail elsewhere).

\section{Fission Track Dating}

Between about 344 and about 500 meters sub-bottom, the measured fission track ages decrease from 76 to 46 m.y.B.P. As shown in Table 2, the 12 glasses from Hole 417D and 1 from Hole 418A show virtually the same agedepth relationship. Size analyses of fossil and induced fission tracks for eight glasses reveal that, in all eight samples, the fossil tracks are smaller than the thermally unaffected induced tracks and that this effect increases with depth (Figure 5). Therefore, the measured ages are all thermally lowered to increasing extents as a function of depth and require correction for the partial loss of fossil tracks (Storzer, 1970; Storzer and Wagner, 1969). From the degree of size reduction of fossil fission tracks, established for the eight samples portrayed in Figure 5, the proper correction factors are found by means of a correction curve calibrated for this type of glasses. This correction curve has a form similar to those published previously (Storzer, 1970; Storzer and Wagner, 1969). When plotting these correction factors versus the logarithm of the sample depth below the sediment cover, a defined relationship between both is obtained (Figure 6). This relationship is to be expected for sites with a thermal gradient defined by a linear temperature increase with depth. As the activation energy which controls the thermal fission track fading increases exponentially with the degree of track fading, the sample depth must consequently also increase exponentially for further track erasure in such a system. This defined relationship allows determination of the age correction factors for the other samples for which fission track sizes were not analyzed but whose depths are known.

The fission track ages corrected for partial, thermal track fading are reported in Table 2 and Figure 7. They scatter between 118 and 99 m.y. B.P. However, this scatter very probably has no real time meaning. In analogy to the fission track ages found for samples from the FAMOUS area (Storzer and Selo, 1974; 1976), it can be assumed that the whole basalt sequence at Hole 417D was formed in a time interval of less than $0.1 \mathrm{~m}$.y. Therefore, a mean age can be calculated which converges to $108.3 \pm 1.3 \mathrm{~m}$.y. This age is interpreted as the formation age of the oceanic crust at Holes 417D and 418A, hence, as the age of magnetic anomaly $M 0$. It should be noted that this fission track age of 108.3 $\pm 1.3 \mathrm{~m}$.y. agrees well with the extrapolated age estimate for $M 0$ of Larson and Hilde (1975).

\section{ACKNOWLEDGMENTS}

We are grateful for the helpful discussions with J. Francheteau and the collaboration of A. Haidmann during the calibration of the integrated neutron fluxes. This work was in part supported by the CNEXO.

\section{REFERENCES}

Fouillac, A. M. and Javoy, M., 1978. Composition isotopique de l'oxygene, de l'hydrogene et du carbone dans la croute atlantique du Leg 51 (IPOD), Abstr. Sixth Réunion annuelle des Sciences de la Terre, p. 167.

Galliker, D., Hugentobler, E., and Hahn, B., 1970. Spontane Kernspaltung von 238-U und 241-Am, Helv. Phys. Acta, v. 43 , p. $593-606$.

Kleeman, J. D. and Lovering, J. F., 1967. Uranium distribution in rocks by fission track registration in Lexan plastic, Science, $v$. 156 , p. $512-513$.

TABLE 2

Fission Track Ages of Glasses From Holes 417D and 418A

\begin{tabular}{|c|c|c|c|c|c|c|}
\hline Lab. No. & Irrad. $^{\mathrm{a}}$ & $\begin{array}{c}\text { Fossil Tracks } \\
\text { per } \mathrm{mm}^{2}\end{array}$ & $\begin{array}{l}\text { Induced Tracks } \\
\text { per } \mathrm{mm}^{2}\end{array}$ & $\begin{array}{c}\text { Measured Fission } \\
\text { Track Age (m.y.B.P.) }\end{array}$ & $\begin{array}{l}\text { Correction Factor } \\
\left(\mathrm{p} / \mathrm{p}_{\mathrm{o}}\right)^{\mathrm{c}}\end{array}$ & $\begin{array}{l}\text { Corrected Fission } \\
\text { Track Age (m.y.B.P.) }\end{array}$ \\
\hline \multirow[t]{2}{*}{ A8 } & $\emptyset 1$ & $384 / 102.19$ & $1206 / 83.21$ & $75.3 \pm 6.8$ & 0.65 & 115.9 \\
\hline & 93 & & $1727 / 50.79$ & $77.0 \pm 6.6$ & & 118.5 \\
\hline A9 & 1 & $214 / 113.44$ & $535 / 61.28$ & $62.8 \pm 7.6$ & 0.55 & 115.2 \\
\hline A10 & 01 & $349 / 234.13$ & $1476 / 186.30$ & $54.6 \pm 4.9$ & 0.51 & 107.1 \\
\hline A11 & 92 & $262 / 109.65$ & $1098 / 82.97$ & $56.8 \pm 5.8$ & 0.50 & 113.6 \\
\hline $\mathrm{A} 12$ & 02 & $176 / 102.32$ & $1111 / 108.25$ & $52.7 \pm 6.1$ & 0.50 & 106.0 \\
\hline \multirow[t]{2}{*}{$\mathrm{A} 13$} & (1) & $426 / 207.16$ & $1181 / 101.94$ & $51.5 \pm 4.5$ & 0.49 & 105.5 \\
\hline & Q2 2 & & $873 / 71.68$ & $53.1 \pm 4.9$ & & 108.4 \\
\hline A14 & $\emptyset 1$ & $398 / 177.68$ & $1790 / 137.49$ & $49.9 \pm 4.2$ & 0.49 & 102.3 \\
\hline A15 & 02 & $360 / 201.05$ & $1125 / 108.51$ & $54.3 \pm 5.0$ & 0.49 & 111.5 \\
\hline A16 & 01 & $1091 / 540.00$ & $3951 / 346.29$ & $51.4 \pm 2.9$ & 0.49 & 106.0 \\
\hline A17 & $\emptyset 1$ & $111 / 73.51$ & $691 / 83.41$ & $52.9 \pm 7.6$ & 0.49 & 109.1 \\
\hline \multirow[t]{3}{*}{ A19 } & 91 & $573 / 238.89$ & $1764 / 123.88$ & $48.9 \pm 3.7$ & 0.46 & 105.6 \\
\hline & (1) 2 & & $793 / 49.17$ & $46.8 \pm 4.1$ & & 101.7 \\
\hline & 93 & & $2303 / 68.24$ & $49.5 \pm 3.6$ & & 107.6 \\
\hline A 20 & 01 & $157 / 66.81$ & $655 / 43.85$ & $45.6 \pm 5.9$ & 0.46 & 98.9 \\
\hline A 25 & 93 & $297 / 218.38$ & $2314 / 125.62$ & $51.4 \pm 4.6$ & 0.48 & 108.2 \\
\hline
\end{tabular}

${ }^{\mathrm{a}} \emptyset 1$ integrated thermal neutron flux: $5.96 \times 10^{15} \mathrm{n} / \mathrm{cm}^{2}, \emptyset 2$ integrated thermal neutron flux: $6.46 \times 10^{15} \mathrm{n} / \mathrm{cm}^{2}, \emptyset 3$ integrated thermal neutron flux: $1.43 \times 10^{16} \mathrm{n} / \mathrm{cm}^{2}$.

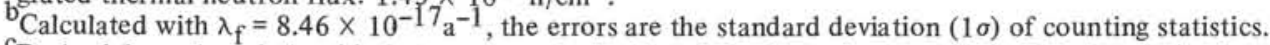

${ }^{\mathrm{c}}$ Derived from the relationship between sample depth and density reduction of fossil fission tracks shown in Figure 6. 


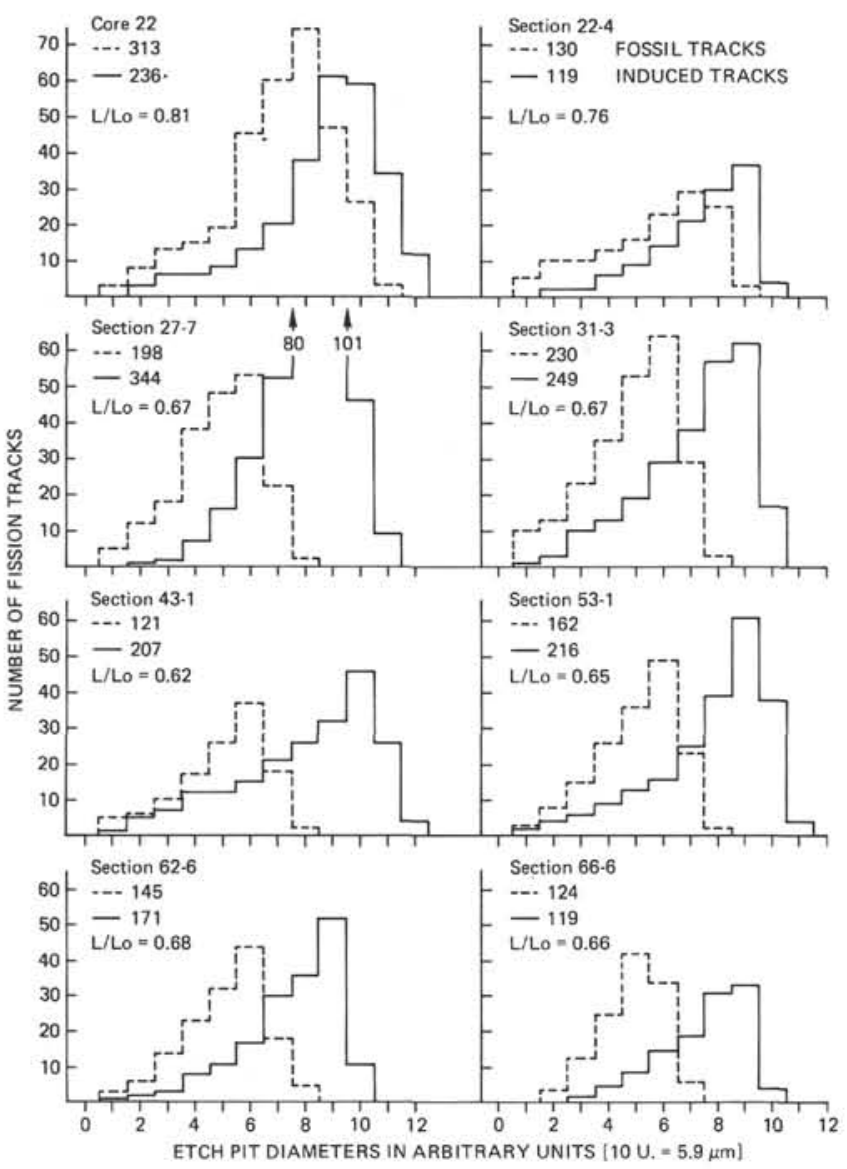

Figure 5. Diameter distribution histograms of fossil and induced fission tracks.

Larson, R. L. and Hilde, T. W. C., 1975. A revised time scale of magnetic reversals for the Early Cretaceous and the Late Jurassic, J. Geophys. Res., v. 80 , p. 2586-2594.

Selo, M. and Storzer, D., 1974. Les traces de fission dans les verres: calibration des paramètres intervenant dans la révélation des traces; leur relation avec le dosage de l'uranium, $C . R$. Acad. Sci. Paris, v. 278, p. 5-8.

Storzer, D., 1970. Fission track dating of volcanic glasses and the thermal history of rocks, Earth Planet. Sci. Lett., v. 8, p. 55-60.

Storzer, D. and Selo, M., 1974. Ages par la méthode des traces de fission de basaltes prélevés dans la vallée axiale de la dorsale médio-atlantique aux environs de $37^{\circ} \mathrm{N}, C$. R. Acad. Sci. Paris, v. 279 , p. $1649-1651$.

, 1976. Uranium contents and fission track ages of some basalts from the FAMOUS area, Bull. Soc. Geol. France, no. 4 , p. $807-810$.

Storzer, D. and Wagner, G. A., 1969. Correction of thermally lowered fission track ages of tektites, Earth Planet. Sci. Lett., v. 5 , p. $463-468$.

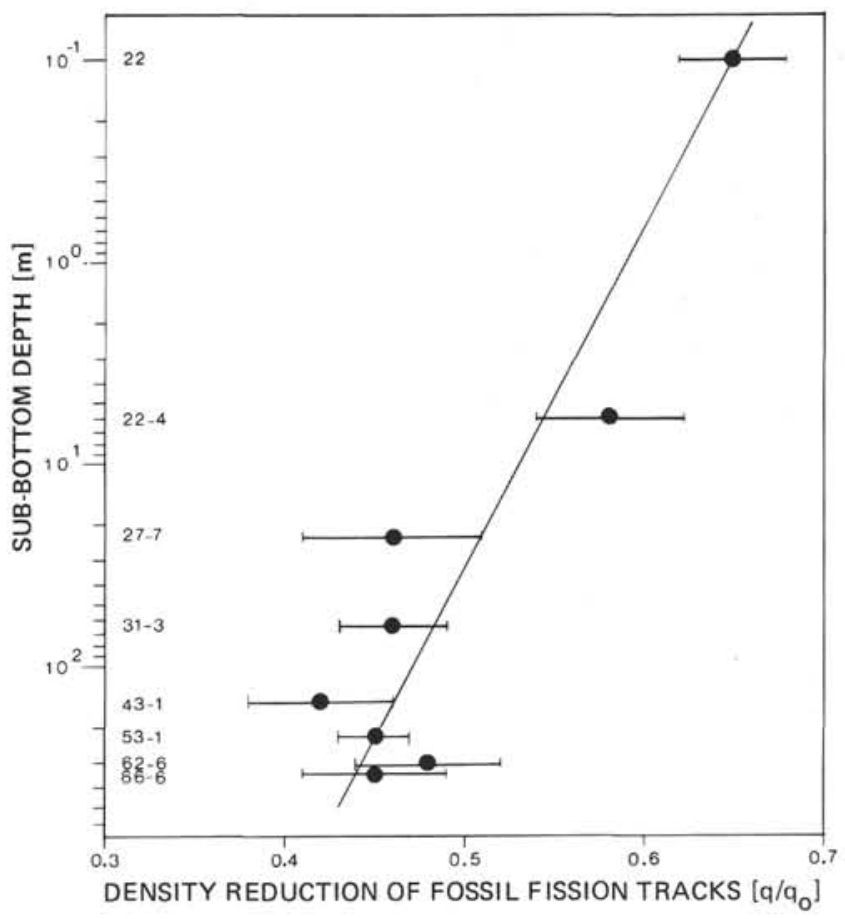

Figure 6. Relationship between sample depth and correction factors for glasses from Hole $417 D$ (see text).

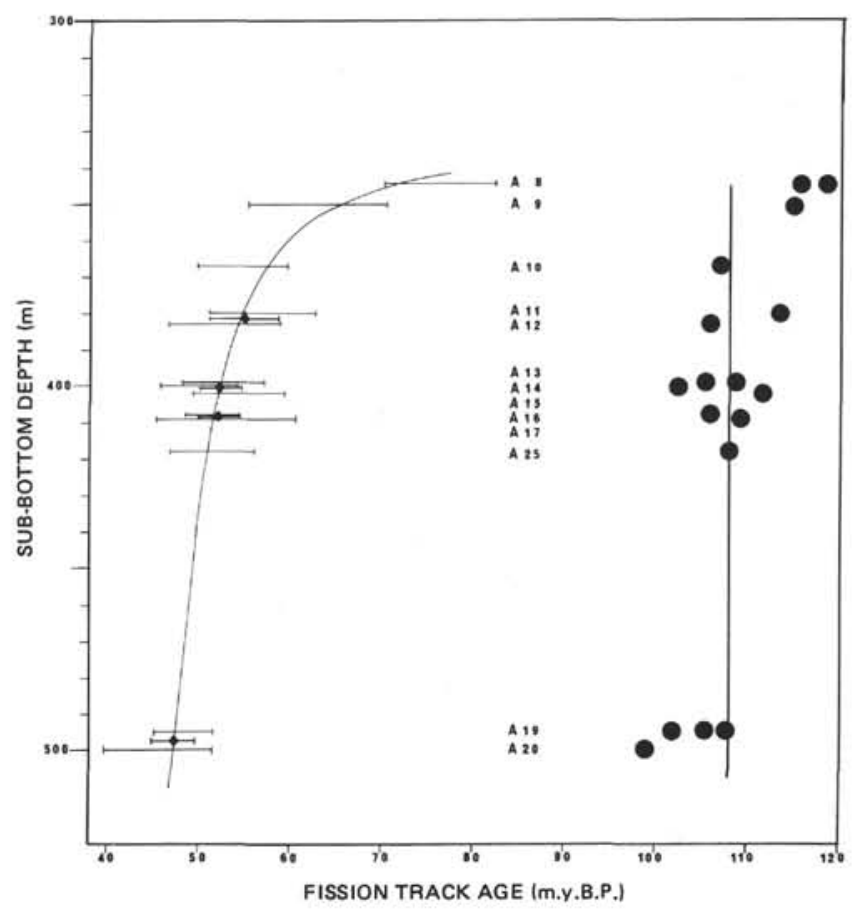

Figure 7. Measured and corrected fission track ages versus sample depth at Holes $417 D$ and 418A. Horizontal bars represent the errors of the measured ages; = mean of two to three measured ages; $\bullet=$ corrected ages. 